\title{
Pengembangan Lembar Kerja Siswa (LKS) Berbasis Inkuiri Terbimbing Materi Sistem Koordinasi Manusia Kelas XI SMAN 5 Taruna Brawijaya Jawa Timur
}

\author{
Risma Widi Aditya, Mumun Nurmilawati, dan Dwi Ari Budiretnani \\ Prodi Pendidikan Biologi, FIKS, Universitas Nusantara PGRI Kediri \\ Email : ${ }^{* 1}$ rismawidiaditya@gmail.com
}

\begin{abstract}
Abstrak
Penelitian ini bertujuan untuk mengetahui kelayakan Lembar Kerja Siswa (LKS) berbasis inkuiri terbimbing materi sistem koordinasi manusia kelas XI di SMAN 5 Taruna Brawijaya Jawa Timur, dan untuk mengetahui respon siswa terhadap Lembar Kerja Siswa (LKS) berbasis inkuiri terbimbing materi sistem koordinasi manusia kelas XI di SMAN 5 Taruna Brawijaya Jawa Timur. Penelitian menggunakan metode pengembangan dengan model ADDIE (Analysis, Design, Development, Implementation, dan Evaluations) tetapi dalam penelitian ini hanya dilaksanakan sampai pada tahap Development (pengembangan). Hasil validasi ahli materi dan bahasa, ahli media, dan praktisi menghasilkan nilai rata-rata berturut-turut 100\%; 89,5\% dan 91,6\% yang menunjukkan sangat valid. Pada nilai respon siswa Lembar Kerja Siswa (LKS) dapat menghasilkan nilai rata-rata $72,3 \%$ dengan kriteria kuat. Dapat disimpulkan bahwa LKS yang dikembangkan dapat dikatakan sangat layak digunakan untuk diterapkan dalam pembelajaran.
\end{abstract}

Kata kunci-Pengembangan Lembar Kerja Siswa (LKS), Inkuiri Terbimbing, Sistem Koordinasi Manusia

\section{PENDAHULUAN}

Beberapa orang menilai bahwa belajar itu sangat membosankan. Rasa bosan itu akan dapat mempengaruhi semangat peserta didik untuk belajar dan akan menurunkan prestasi peserta didik. Faktor utama yang mempengaruhi rasa bosan itu berasal dari diri kita sendiri maupun adanya pengaruh di luar lingkungan yang kita tempati [1]. Belajar adalah perubahan tingkah laku, dan terjadi karena hasil pengalaman. Belajar itu sebagai proses aktif internal individu dimana melalui pengalamannya berinteraksi dengan lingkungan menyebabkan terjadinya perubahan tingkah laku yang relatif permanen.

Pembelajaran terdiri dari proses belajar dan mengajar yang merupakan inti penting dari pendidikan. [2] Pendidikan merupakan usaha sadar dan terencana untuk mewujudkan suasana belajar dan proses pembelajaran agar siswa dapat secara aktif mengembangkan potensi yang ada pada dirinya untuk mempunyai kekuatan spiritual, penguasaan diri, kepribadian, kecerdasan, akhlak yang mulia dan keterampilan yang diperlukan dirinya, masyarakat, bangsa dan negara. Fungsi dari pendidikan adalah mengembangkan kemampuan dan membentuk kepribadian, bertujuan untuk berkembangnya potensi siswa agar menjadi manusia yang beriman, serta bertakwa kepada Tuhan Yang Maha Esa, memiliki akhlak mulia, sehat, berilmu, cakap, kreatif, mandiri, dan menjadi warga negara yang demokratis serta mempunyai sikap tanggung jawab.

Dalam dunia pendidikan harus ada interaksi antara guru dan peserta didik dalam proses pembelajaran. Salah satu tugas guru adalah untuk mencerdaskan generasi bangsa. Oleh karena itu, guru harus menggunakan buku pedoman untuk memperlancar proses pembelajaran. Banyak buku pedoman yang dapat digunakan oleh guru sebagai referensi, seperti bahan ajar. Bahan ajar terdiri dari beberapa bagian dan salah satunya adalah LKS. LKS merupakan alat belajar peserta didik yang memuat berbagai kegiatan yang akan dilaksanakan oleh peserta didik secara aktif. LKS dapat dijadikan sebagai bahan untuk penambah pengetahuan peserta didik, karena LKS banyak berisikan soal-soal untuk menguji kemampuan peserta didik. [3] LKS merupakan suatu bahan ajar cetak berupa lembaran-lembaran kertas yang berisi ringkasan materi, soal-soal dan petunjuk-petunjuk pelaksanaan tugas pembelajaran yang harus dikerjakan oleh peserta didik, yang mengacu pada kompetensi dasar yang harus dicapai dan tersusun secara sistematis. Urutan materi yang sistematis pada LKS membantu peserta didik mempelajari materi dengan baik.

Berdasarkan hasil observasi yang telah dilakukan di SMAN 5 Taruna Brawijaya Jawa Timur terdapat beberapa masalah yang ada pada proses pembelajaran. Lebih dari $80 \%$ saat pembelajaran berlangsung guru biologi menggunakan metode ceramah, sisanya sedikit tanya jawab, baik secara individu maupun kelompok. Pembelajaran biologi tersebut bersifat membosankan, tidak menarik, dan tidak berminat untuk aktif dalam proses pembelajaran yang dikarenakan guru biologi rata-rata gaya mengajaranya kurang dipahami oleh siswa. Hal ini terbukti dari banyaknya siswa yang tidak mengerjakan tugasnya, dan malas untuk membaca buku. Selama proses pembelajaran siswa lebih banyak pasif dalam mengerjakan LKS.

Upaya untuk mengatasi masalah tersebut dengan melakukan praktikum. Kegiatan praktikum pada materi sistem koordinasi manusia belum pernah dilakukan meskipun alat dan bahan untuk praktikum tersedia, 
hanya melakukan perkenalan alat dan bahan yang ada di laboratorium, sehingga membuat siswa masih belum bisa memahaminya. Dari hasil angket siswa, pembelajaran biologi di SMAN 5 Taruna Brawijaya Jawa Timur masih menggunakan media yang membuat semua siswa menghafal materi dan tanpa tahu prosesnya secara langsung khusunya pada materi sistem koordinas manusia yang dikarenakan guru biologi tidak melakukan pratik langsung di laboratorium. Pada saat diskusi yang dilakukan oleh siswa masih banyak yang membuat siswa belum aktif secara maksimal. Kegiatan diskusi mengajak siswa untuk mencari materi dari beberapa referensi buku yang di dapatkan. Sedangkan ketika melakukan presentasi hasil diskusinya, masih banyak siswa yang kurang memperhatikan karena sudah merasa memiliki materi-materi yang disajikan meskipun belum paham sepenuhnya.

Berdasarkan pengamatan yang diperoleh, guru menggunakan LKS sebagai acuan media pembelajaran. Akan tetapi yang digunakan guru LKS yang berisi tentang kumpulan materi-materi dan soal-soal latihan. Hal ini siswa memerlukan adanya LKS penuntun eksperimen untuk dapat memahami beberapa konsep materi sistem koordinasi manusia dengan baik. Sebaiknya LKS tersebut dapat memuat langkah-langkah kegiatan yang bisa mendukung eksperimen yaitu inkuiri terbimbing.

LKS berbasis inkuiri terbimbing yang berisi tentang kegiatan percobaan atau praktikum tentang macam-macam sistem koodinasi manusia. Melalui tentang macam-macam sistem koordinasi manusia diharapakan LKS ini dapat membuat siswa berpikir lebih kritis untuk menganalisis dan menyimpulkan dari kegiatan yang dilakukan. Hal ini siswa dapat menemukan masalah-masalah dari percobaaan tersebut sehingga siswa dapat merangsang dalam menemukan konsep itu sendiri dan melatih siswa untuk bisa berpikir tingkat tinggi dan dapat menyelesaikan masalah yang ada melalui pertanyaan yang berhubungan dengan percobaan yang sedang dilakukan.

Strategi pembelajaran inkuiri terbimbing adalah serangkaian kegiatan pembelajaran yang menekankan pada proses berpikir secara kritis dan analitis untuk mencari dan menemukan sendiri jawaban yang sudah pasti dari suatu masalah yang ditanyakan [4]. Inkuiri terbimbing merupakan pembelajaran yan melibatkan siswa dalam menemukan pengetahuan dan pemahaman, sehingga hal penting dan menjadi patokan dalam pembelajaran inkuiri adalah pembelajaran yang dapat terjadi apabila pembelajar diminta untuk mendapatkan sesuatu [5].

Inkuiri terbimbing memiliki kelebihan yang dapat ditemukan [6] sebagai berikut, 1) menekankan kepada pengembangan aspek kognitif, afektif dan psikomotor secara seimbang, sehingga pengajaran melalui strategi ini lebih bermakna; 2) memberikan kesempatan kepada siswa untukk belajar sesuai dengan gaya belajarnya; 3) sesuai dengan perkembangan psikologis belajar modern yang menganggap belajar adalah proses perubahan tingkah laku lewat pengalaman; 4) mampu melayani kebutuhan siswa yang memilki kemampuan di atas rata-rata, sehingga siswa yang memiliki kemampuan belajar bagus tidak akan terhambat oleh siswa yang lemah dalam belajar.

Berdasarkan permasalahan yang telah diuraiakan, maka perlu dikembangkan LKS berbasis inkuiri terbimbing pada materi sistem koordinasi manusia. Sehingga diharapkan LKS yang dikembangkan dapat membantu siswa dalam memahami konsep sistem koordinasi manusia. Tujuan dari penelitian ini adalah 1) untuk mengetahui kelayakan LKS berbasis inkuiri terbimbing materi sistem saraf kelas XI di SMAN 5 Taruna Brawijaya Jawa Timur; 2) Untuk mengetahui respon siswa terhadap LKS berbasis inkuiri terbimbing materi sistem saraf kelas XI di SMAN 5 Taruna Brawijaya Jawa Timur. Kemudian manfaat dari penelitian ini adalah 1) sebagai tambahan pengetahuan untuk menjadi seorang pendidik dalam pengembangan LKS berbasisi inkuiri terbimbing untuk meningkatkan hasil belajar yang baik, khususnya dalam pembelajaran biologi; 2) sebagai acuan dalam menumbuhkan minat dan motivasi belajar siswa; 3) Sebagai acuan dalam mendorong siswa untuk dapat berperan aktif dalam proses pembelajaran; (4) sebagai acuan dalam membantu siswa untuk dapat berpikir kreatif dan benar-benar bisa memahami konsep biologi yang di anggap sulit karena materi dikaitkan dengan kehidupan sehari-hari dan lingkungan dunia nyata siswa.

\section{METODE PENELITIAN}

Metode penelitian yang digunakan adalah (Research and Development / $R$ \& D) [7]. Model pengembangan yang digunakan adalah model ADDIE yaitu: Analysis, Design, Development, Implementation, Evaluation [8] dalam penelitian ini dibatasi pada tahap Development (pengembangan).

Tahap Analysis (analisis) merupakan suatu proses mendefinisikan apa yang akan dipelajari oleh peserta didik. Pada tahap ini dilakukan analisis masalah perlunya suatu pengembangan. Maka untuk mengetahui atau menentukan apa yang harus dipelajari, kita harus melakukan beberapa kegiatan, diantaranya analisis kebutuhan, analisis materi, analisis kurikulum, dan analisis karakteristik siswa. Tahap Design (desain) tahap ini dikenal juga dengan istilah membuat rancangan. Perancangan LKS dilakukan berdasarkan hal-hal 
Jurnal Biologi dan Pembelajarannya, Vol 7 No 2, Oktober 2020. Pp: 28-35

e-ISSN: $2406-8659$

yang diperoleh dari tahap analisis. Kegiatan yang dilakukan pada tahap perancangan meliputi, 1) menentukan judul LKS; 2) penulisan draft LKS; 3) menyiapkan buku referensi yang berkaitan dengan materi sistem koordinasi manusia; 4) menyusun peta kebutuhan LKS; 5) penyusun desain LKS. Tahap Development (pengembangan) merupakan proses mewujudkan desain tadi yang menjadi kenyataan maka LKS tersebut perlu dikembangkan. Peneliti meminta ketersediaan tiga orang validator untuk melakukan penilaian terhadap validitas LKS, validator tersebut yaitu, ahli materi dan bahasa yaitu Dra. Budhi Utami, M.Pd dosen pendidikan biologi Universitas Nusantara PGRI Kediri dan Sulistyono Tyas Wigino, S.Pd selaku guru pelajaran biologi di SMAN 5 Taruna Brawijaya Jaya Jawa Timur, ahli media yaitu Dr. Aan Nurfahrudianto, M.Pd dosen Universitas Nusantara PGRI Kediri. Pada penelitian ini, hanya dibatasi pada uji validitas dan uji respon siswa.

Data angket validasi tentang tanggapan ahli terkait kelayakan LKS dianalisis menggunakan analisis deskriptif dengan rumus sebagai berikut :

$$
P=\frac{\sum x}{\sum x i} X 100 \%
$$

Keterangan :

$P$ : persentase validasi

$\sum \mathrm{x}$ : jumlah skor jawaban responden dalam satu item

Skor 4 = sangat setuju

Skor $3=$ setuju

Skor 2 = kurang setuju

Skor 1 = sangat tidak setuju

$\sum \mathrm{xi}=$ jumlah skor ideal dalam satu item pertanyaan

$100 \%=$ konstanta $[9]$

Nilai tersebut kemudian dikonversikan dengan kriteria penilaian dalam Tabel 1 sebagai berikut :

Tabel 1 kriteria penilaian validasi Lembar Kerja Siswa (LKS)

\begin{tabular}{cc}
\hline Interval Validasi LKS & Kriteria Penilaian \\
\hline $90 \%-100 \%$ & Sangat Valid \\
$75 \%-89 \%$ & Valid \\
$65 \%-74 \%$ & Cukup Valid \\
$40 \%-64 \%$ & Kurang Valid \\
$0 \%-39 \%$ & Tidak Valid \\
\hline
\end{tabular}

Data angket respon siswa terhadap LKS berbabis inkuiri terbimbing materi sistem koordinasi manusia yang digunakan untuk mengetahui respon siswa terhadap LKS yang dikembangkan. Penskoran angket respon siswa dengan memberikan tanda ( $\sqrt{ }$ ) pada pilihan respon siswa, yaitu : SS/Sangat Setuju (skor 4), S/Setuju (skor 3), TS/Tidak Setuju (skor 2), STS/Sangat Tidak Setuju (skor 1).

Selajutnya nilai respon siswa dijumlah untuk tiap butir pertanyaan dan dicari persentase dengan rumus sebagai berikut :

$$
\% N R S=\frac{\sum N R S}{N R S \text { maksimum }} \times 100 \%
$$

Keterangan :

$\%$ NRS $=$ Persentase

$\sum N R S=$ Total nilai respon siswa yang diperoleh dari NRS SS + NRS S + NRS TS + NRS STS

NRS maksimum : $\sum \mathrm{R} \times$ skor pilihan terbaik $=\sum \mathrm{R} \times 4$

Dengan menggunakan tabel 2, persentase siswa akan mampu dijelaskan kriteriannya [10]

Tabel 2. Kriteria Persentase Nilai Respon Siswa

\begin{tabular}{c|c}
\hline Persentase & Kriteria \\
\hline $0 \% \leq$ NRS $20 \%$ & Sangat Lemah \\
\hline
\end{tabular}


Jurnal Biologi dan Pembelajarannya, Vol 7 No 2, Oktober 2020. Pp: 28-35

e-ISSN: $2406-8659$

\begin{tabular}{c|c}
\hline $20 \% \leq$ NRS $40 \%$ & Lemah \\
$40 \% \leq$ NRS $60 \%$ & Cukup \\
$60 \% \leq$ NRS $80 \%$ & Kuat \\
$80 \% \leq$ NRS $100 \%$ & Sangat Kuat \\
\hline
\end{tabular}

\section{HASIL DAN PEMBAHASAN}

Berdasarkan hasil observasi dilapangan ditemukan beberapa permasalahan yang dapat menghambat proses pembelajaran yaitu siswa kurang aktif dalam pembelajaran, terutama ketika pembelajaran mandiri yang menggunakan LKS. Siswa mengaku kurang berminat dalam menggunakan LKS dan mengalami kesulitan ketika pembelajaran biologi, karena LKS sulit dipahami dan cenderung kurang menarik. Berdasarkan temuan tersebut kemudian dibuat peta konsep sebagai acuan untuk mengembangkan LKS berbasis inkuiri terbimbing pada materi sistem koordinasi manusia.

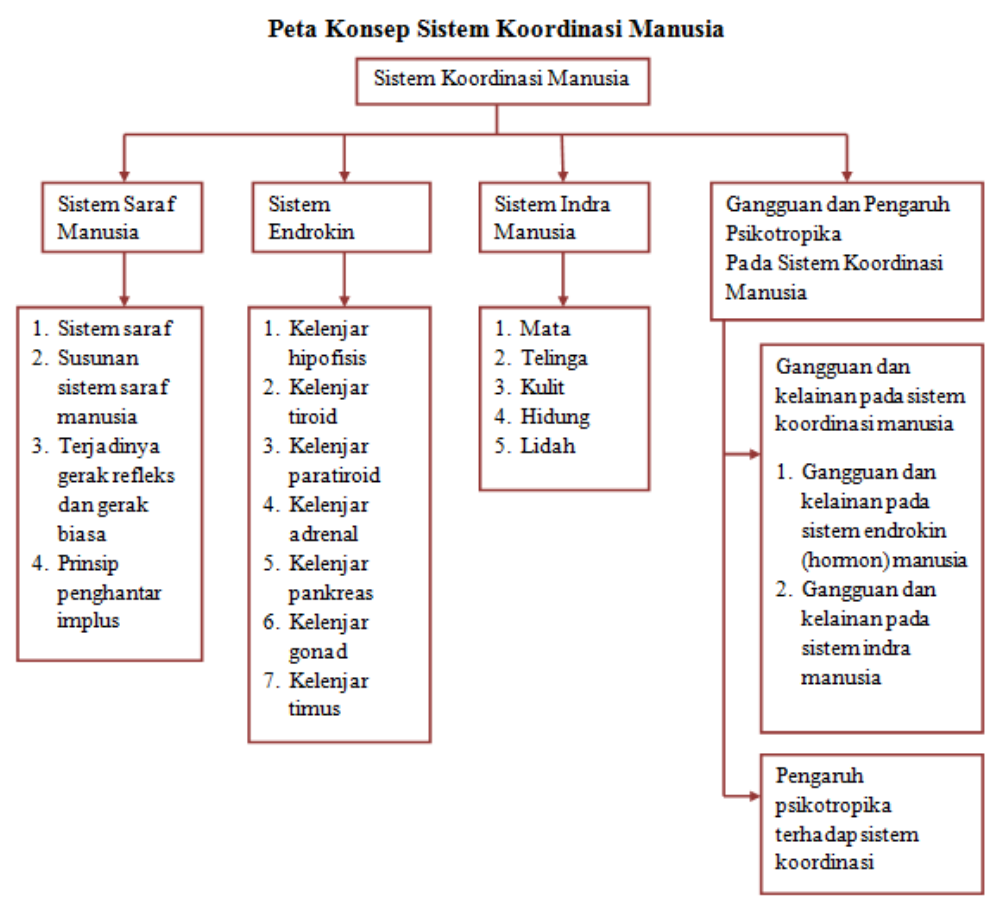

Gambar 1. Peta Konsep Sistem Koordinasi Manusia

Desain LKS terdiri dari cover/sampul (gambar 2) identitas siswa meliputi (nama, kelas, nomer absen dan sekolah), kompetensi dasar (KD), indikator dan tujuan pembelajaran, kegiatan belajar siswa yang berbasis inkuiri terbimbing. langkah-langkah pembelajaran berdasarkan inkuiri terbimbing adalah sebagai berikut :

1. Wacana

Wacana yang dimuat dalam LKS ini berisi tentang masalah-masalah yang ditemukan dalam kehidupan sehari-hari. Wacana tersebut bertujuan agar siswa mampu mengidentifikasi masalah dalam bacaan tersebut. Wacana dalam LKS merupakan tahapan penyajian masalah berdasarkan strategi inkuiri terbimbing.

\section{Diskusi Kelompok}

Penugasan diskusi ditempatkan pada setiap bagian LKS. Pada kegiatan diskusi meliputi beberapa tahapan sebagai berikut :

\section{a. Rumusan Masalah}


Jurnal Biologi dan Pembelajarannya, Vol 7 No 2, Oktober 2020. Pp: 28-35

e-ISSN: $2406-8659$

Tahap merumuskan masalah dilakukan setelah siswa membaca wacana.

b. Hipotesis

Membuat hipotesis berdasarkan rumusan masalah yang sudah dibuat.

c. Kegiatan Eksperimen

Kegiatan eksperimen merupakan tahapan mengumpulkan data untuk membuktikan hipotesis yang dibuat. Dalam kegiatan eksperimen terdapat tujuan eksperimen, penentuan hari dan tanggal eksperimen, menyiapkan alat dan bahan yang digunakan dalam eksperimen. Melakukan eksperimen yang sesuai dengan langkah kerja, mengisi tabel pengamatan sesuai dengan hasil eksperimen.

3. Evaluasi Hipotesis

Evaluasi hipotesis merupakan tahapan inkuiri terbimbing yang dilakukan siswa untuk memilih hipotesis yang valid dan yang sesuai dengan hasil percobaan.

4. Menyimpulkan

Menyimpulkan merupakan tahapan terakhir dari inkuiri terbimbing. Pada tahap ini siswa membuat sebuah kesimpulan berdasarkan hasil eksperimen yang telah dilakukan.

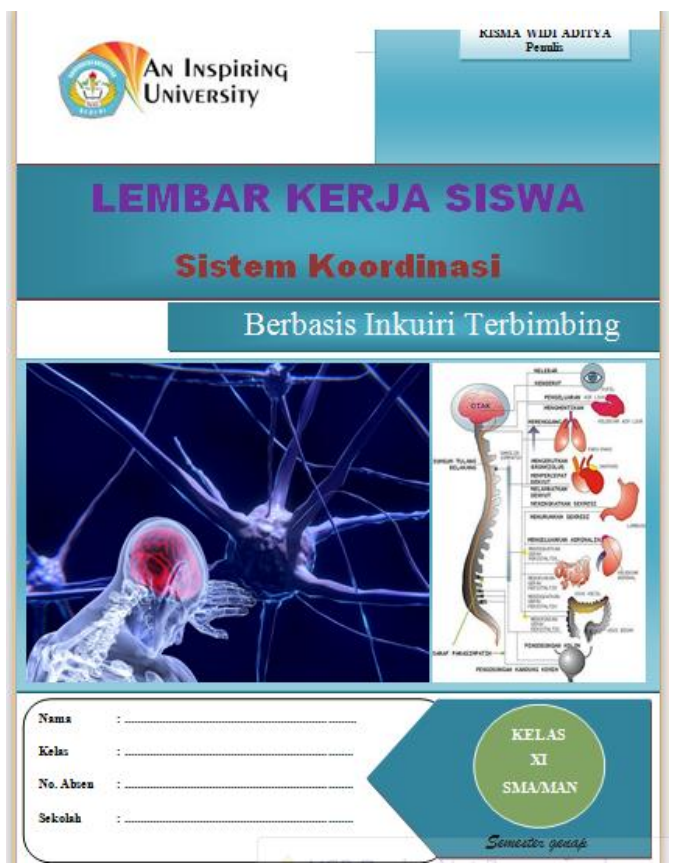

Gambar 2. Cover/Sampul LKS

Berikut ini adalah hasil penilaian validasi oleh ahli media dan bahasa yang akan dikembangkan dapat dilihat selengkapnya pada tabel 3

Tabel 3. Hasil Validasi LKS oleh Ahli Materi dan Bahasa

\begin{tabular}{c|l|c|c}
\hline No. & \multicolumn{1}{|c|}{ Aspek yang dinilai } & P (\%) & Kriteria \\
\hline 1. & Cover/sampul & 100 & Sangat Valid \\
2. & Tujuan Pembelajaran & 100 & Sangat Valid \\
3. & Kegiatan Belajar Siswa & 100 & Sangat Valid \\
4. & Materi & 100 & Sangat Valid \\
5. & Eksperimen & 100 & Sangat Valid \\
6. & Tabel & 100 & Sangat Valid \\
\hline
\end{tabular}


Jurnal Biologi dan Pembelajarannya, Vol 7 No 2, Oktober 2020. Pp: 28-35

e-ISSN: $2406-8659$

\begin{tabular}{c|l|l|l}
\hline 7. & Soal Latihan Mandiri & 100 & Sangat Valid \\
8. & Daftar Rujukan & 100 & Sangat Valid \\
\hline Rata-rata & $\mathbf{1 0 0}$ & Sangat Valid \\
\hline
\end{tabular}

Berdasarkan hasil validasi ahli materi dan bahasa pada tabel 3 diketahui sebagian besar aspek yang dinilai dalam LKS ini menunjukkan kriteria sangat valid yang diperoleh dengan skor rata-rata $100 \%$ sehingga tidak ada yang perlu di revisi.

Tabel 4. Hasil Validasi LKS oleh Ahli Media

\begin{tabular}{c|l|c|c}
\hline No. & \multicolumn{1}{|c|}{ Aspek yang dinilai } & P (\%) & Kriteria \\
\hline 1. & Cover/sampul & 75 & Valid \\
2. & Kata Pengantar & 100 & Sangat Valid \\
3. & Daftar Isi & 100 & Sangat Valid \\
4. & Peta Konsep & 100 & Sangat Valid \\
5. & Petunjuk Pengguna LKS bagi siswa & 100 & Sangat Valid \\
6. & Tujuan Pembelajaran & 50 & Cukup Valid \\
7. & Kegiatan Belajar Siswa & 100 & Sangat Valid \\
8. & Prosedur Kerja & 100 & Sangat Valid \\
9. & Soal Pendalaman & 100 & Sangat Valid \\
10. & Tabel & 100 & Sangat Valid \\
11. & Soal Mandiri & 75 & Valid \\
12. & Daftar Pustaka & 75 & Valid \\
\hline \multicolumn{2}{l|}{ Rata-rata } & $\mathbf{8 9 , 5}$ & Sangat Valid \\
\hline
\end{tabular}

Berdasarkan hasil validasi ahli media pada tabel 4 diketahui sebagian besar aspek yang dinilai dalam LKS ini menunjukkan kriteria sangat valid, cukup valid dan valid yang diperoleh dengan skor rata-rata $89,5 \%$ sehingga tidak ada yang perlu di revisi. Tetapi ada satu aspek pada tujuan pembelajaran yang menunjukkan kriteria cukup valid dengan presentase $50 \%$ berarti perlu adanya revisi.

Tabel 5. Hasil Validasi LKS oleh Guru

\begin{tabular}{c|l|c|c}
\hline No. & \multicolumn{1}{|c|}{ Aspek yang dinilai } & P (\%) & Kriteria \\
\hline 1. & Cover/sampul & 91,6 & Sangat Valid \\
2. & Peta Konsep & 100 & Sangat Valid \\
3. & Petunjuk pengguna LKS bagi siswa & 100 & Sangat Valid \\
4. & Daftar Isi & 100 & Sangat Valid \\
5. & Tujuan Pembelajaran & 100 & Sangat Valid \\
6. & Kegiatan belajar yang berbasis inkuiri terbimbing & 89,2 & Sangat Valid \\
7. & Materi/dasar teori & 87,5 & Sangat Valid \\
8. & Alat dan Bahan & 87,5 & Sangat Valid \\
9. & Prosedur Kerja & 87,5 & Sangat Valid \\
10. & Tabel & 100 & Sangat Valid \\
11. & Bahan Diskusi & 85 & Sangat Valid \\
12. & Soal Mandiri & 87,5 & Sangat Valid \\
13. & Daftar Rujukan & 75 & Valid \\
\hline \multicolumn{2}{l}{ Rata-rata } & $\mathbf{9 1 , 6}$ & Sangat Valid \\
\hline
\end{tabular}

Berdasarkan hasil validasi oleh guru biologi pada tabel 5 diketahui sebagian besar aspek yang dinilai dalam LKS ini menunjukkan kriteria sangat valid dan valid yang diperoleh dengan skor rata-rata 91,6\% sehingga tidak perlu adanya revisi dan LKS ini dapat dikatakan sangat valid untuk diterapkan dalam pembelajaran biologi materi sistem koordinasi manusia.

Tabel 6. Hasil Penilaian Respon Siswa Kelas XI Tentang LKS

\begin{tabular}{c|l|c|c|c|c|c|c|c|c|c|c}
\hline No. & \multicolumn{1}{|c|}{ Aspek yang dinilai } & \multicolumn{1}{|c|}{ \%NRS } \\
\cline { 3 - 11 } & & $\mathbf{1}$ & $\mathbf{2}$ & $\mathbf{3}$ & $\mathbf{4}$ & $\mathbf{5}$ & $\mathbf{6}$ & $\mathbf{7}$ & $\mathbf{8}$ & $\mathbf{9}$ & $\mathbf{1 0}$ \\
\hline 1. & Cover/Sampul & 87,5 & 100 & 75 & 75 & 75 & 100 & 75 & 87,5 & 75 & 75 \\
2. & Petunjuk Penggunaan LKS bagi & 75 & 100 & 100 & 100 & 75 & 100 & 75 & 75 & 75 & 100 \\
& Siswa & & & & & & & & & & \\
3. & Daftar Isi & 75 & 75 & 100 & 100 & 100 & 100 & 100 & 75 & 100 & 100 \\
4. & Tujuan Pembelajaran & 75 & 75 & 75 & 100 & 100 & 100 & 100 & 100 & 75 & 75 \\
\hline
\end{tabular}




\begin{tabular}{c|l|c|c|c|c|c|c|c|c|c|c}
\hline 5. & Kegiatan Belajar Siswa & 75 & 75 & 75 & 100 & 75 & 100 & 75 & 100 & 75 & 75 \\
6. & Materi/Dasar Teori & 75 & 100 & 75 & 87,5 & 75 & 100 & 75 & 87,5 & 75 & 75 \\
7. & Alat dan Bahan & 100 & 100 & 100 & 100 & 75 & 100 & 75 & 75 & 100 & 75 \\
8. & Langkah Kerja & 100 & 75 & 75 & 100 & 75 & 100 & 75 & 100 & 75 & 75 \\
9. & Tabel & 100 & 75 & 75 & 100 & 100 & 75 & 100 & 75 & 75 & 75 \\
10. & Bahan Diskusi & 75 & 100 & 87,5 & 100 & 75 & 87,5 & 75 & 100 & 87,5 & 75 \\
11. & Soal Mandiri & 75 & 100 & 87,5 & 87,5 & 87,5 & 87,5 & 75 & 75 & 87,5 & 100 \\
12. & Daftar Rujukan & 75 & 100 & 100 & 100 & 87,5 & 100 & 87,5 & 75 & 75 & 75 \\
\hline Rata-rata & $\mathbf{8 8 , 5}$ & $\mathbf{8 9 , 5}$ & $\mathbf{8 5 , 4}$ & $\mathbf{9 5 , 8}$ & $\mathbf{8 3 , 3}$ & $\mathbf{9 5 , 8}$ & $\mathbf{8 2 , 2}$ & $\mathbf{8 5 , 4}$ & $\mathbf{8 1 , 2}$ & $\mathbf{8 1 , 2}$ \\
\hline Rata-rata \%NRS & \multicolumn{8}{|c|}{ Kuat } \\
\hline
\end{tabular}

Berdasarkan hasil respon siswa terhadap LKS oleh 10 siswa Kelas XI SMAN 5 Taruna Brawijaya Jawa Timur LKS dapat diketahui sebagian besar aspek yang dinilai dalam LKS ini menujukkan kriteria kuat yang diperoleh rata-rata $72,3 \%$ sehingga tidak ada yang di revisi. Siswa merasa senang dan memahami materi sistem koordinasi manusia dengan menggunakan LKS berbasis inkuiri terbimbing yang dikembangkan oleh peneliti, bahasa yang digunakan mudah dipahami, LKS berbaisis inkuiri tebimbing sangat sederhana dan menarik, sehingga siswa termotivasi untuk belajar.

Berdasarkan hasil kritik dan saran dari ahli materi dan bahasa, ahli media, guru dan siswa adalah hasil kitik dan saran oleh ahli materi dan bahasa yaitu LKS sudah baik dan dapat digunakakan namun ada beberapa yang perlu direvisi yaitu pada latihan soal mandiri. Pada soal "Kelenjar endokrin bekerja hanya sampai saat tertentu saja adalah" dengan perbaikan "Kelenjar endokrin yang bekerja mengatur kadar gula darah adalah". Hal tersebut sependapat dengan penelitian yang dilakukan oleh Rizqiyana bahwa bahasa pertanyaan diperbaiki dengan menambahkan beberapa pertanyaan pendahuluan [11].

Hasil kritik dan saran oleh ahli media yaitu menyatakan bahwa LKS layak digunakan tetapi dengan beberapa perbaikan yaitu penulisan tujuan pembelajaran, pembuatan soal disesuaikan dengan KD, kemudian soal lebih disederhanakan. Hal tersebut sesuai dengan penelitian yang dilakukan oleh Hafshohnmengemukakan bahwa tujuan pembelajaran disesuaikam dengan KD, tujuan pembelajaran yang dirumuskan berdasarkan KD dengan menggunakan kata kerja operasional yang dapat diamati dan diukur, yang mencakup sikap, pengetahuan, dan keterampilan [12].

Hasil kritik dan saran oleh guru yaitu LKS sudah sesuai dengan konsep, pada materi sudah bisa membantu siswa untuk memecahkan permasalahan dalam proses pembelajaran. Hal tersebut sesuai dengan penelitian yang dilakukan oleh Lutfiana LKS sesuai dengan konsep, materi dan soal-soal yang dibuat dapat membantu siswa dalam mengerjakan secara individu dan LKS berbasis inkuiri terbimbing sangat baik dari segi bahasa, ukuran, dan serta spasi sudah sesuai sehingga siswa dapat dengan mudah memahami materi pembelajaran yang ada di dalam LKS berbasis inkuiri terbimbing dan juga menuntun siswa untuk terbiasa berpikir runut [13].

Sedangkan hasil ktitik dan saran pada siswa sampul sudah sangat menarik, LKS berbasis inkuri terbimbing berbeda dengan LKS yang sebelum-sebelumnya karena LKS ini sederhana dalam memberikan praktiknya dan bisa memudahkan dalam proses pembelajaran. Hal ini sependapat dengan penelitian yang dilakukan oleh Rohmah yang menyatakan sebuah sampul itu harus menarik dalam segi penggunaan gambar dan warna sampul, LKS berbasis inkuiri terbimbing mudah dipahami oleh siswa baik dari segi bahasa yang digunakan dan kemudahan dalam kemampuan memahami konsep serta bisa memecahkan masalah dalam proses pembelajaran [14]. Dari hasil respon siswa LKS hal ini dapat dilihat dari rata-rata $72,3 \%$ dengan kriteria kuat tanpa ada revisi. Hal tersebut juga sesuai dengan penelitian yang dilakukan oleh Lestari dalam penelitiannya menunjukkan bahwa media Atlas Invertebrata adalah media ini dapat digunakan atau diterapkan pada pembelajaran biologi di sekolah dengan baik, hal ini dapat dilihat dari rata-rata post test siswa yaitu telah memahami isi atlas invertebrata dengan baik, hasil respon siswa terhadap media atlas invertebrata dinyatakan sangan kuat tanpa ada revisi [15].

\section{SIMPULAN}

Dari hasil penelitian dapat disimpulkan bahwa LKS berbasis inkuiri terbimbing materi sistem koordinasi telah dinyatakan layak oleh validator ahli materi dan bahasa, ahli media, guru dan siswa, sehingga layak digunakan untuk proses pembelajaran siswa Kelas XI SMAN 5 Taruna Brawijaya Jawa Timur pada materi sistem koordinasi manusia.

\section{SARAN}


Jurnal Biologi dan Pembelajarannya, Vol 7 No 2, Oktober 2020. Pp: 28-35

e-ISSN: $2406-8659$

Meskipun produk yang telah dikembangkan masih memiliki kekurangan dan keterbatasan waktu, namun peneliti berharap produk yang telah dikembangkan dapat memberikan kontribusi positif dalam dunia pendidikan. Adapun saran yang dapat menjadi pertimbangan dalam mewujudkan harapan peneliti adalah sebagai berikut :

1. Penelitian pengembangan ini hanya sampai pada tahap Development, sehingga kedepannya dapat dilakukan penelitian sampai tahap Implementation (uji coba kelompok besar) dan tahap Evaluations (evaluasi) sehingga dapat diketahui keefektifan LKS.

2. LKS dapat digunakan acuan untuk penelitian lebih lanjut pada materi lain misalkan pada materi sistem ekskresi, sehingga harapan peneliti akan muncul produk-produk baru bahkan jauh lebih baik lagi sehingga memberikan inovasi dan pembaharuan LKS secara berkesinambungan.

\section{UCAPAN TERIMAKASIH}

\section{DAFTAR PUSTAKA}

[1] Nengsi, S. \& Afriani, W. (2019). Pengembangan LKS Biologi Berbasis Inkuiri Terbimbing Materi Sistem Regulasi. Jurnal Pendidikan Biologi dan Sains, 2, 50-59.

[2] Undang-Undang Republik Indonesia Nomor 20. Tahun 2003. Tentang Sistem Pendidikan Nasional. Semarang: Aneka Ilmu.

[3] Prastowo, A. (2015). Panduan Kreatif Membuat Bahan Ajar Inovatif: Menciptakan Metode Pembelajaran yang Menarik dan Menyenangkan. Banguntapan Jogjakarta: DIVA Press.

[4] Sanjaya, W. 2010. Strategi Pembelajaran Berorientasi Standar Proses Pendidikan. Jakarta: Kencana Prenada Media Group.

[5] Nurdyansyahdan Fahyuni, E.F. 2016. Inovasi Model Pembelajaran Sesuai Kurikulum 2013. Sidoarjo: Nizamila Learning Center.

[6] Hamruni. 2012. Strategi Pembelajaran. Yogyakarta: Insan Madani.

[7] Sugiyono. 2017. Metode Penelitian Kuantitatif, Kualitatif, dan R\&D. Alfabeta, Bandung.

[8] Pribadi, A. Benny. (2011). Model Desain Sistem Pembelajaran: Langkah Penting Merancang Kegiatan Pembelajaran yang Efektif dan Berkualitas. Jakarta: Dian Rakyat

[9] Julita, K.D. 2018. Pengembangan Perangkat Pembelajaran Materi Animalia Berbasis Model Pembelajaran Inkuiri Terbimbing Untuk Meningkatkan Hasil Belajar Siswa SMA Negeri 3 Kota Kediri Kelas MIPA 2.2. Skripsi. Kediri: Universitas Nusantara PGRI Kediri.

[10] Puspitasari, P. 2017. Pengembangan Model Invertebrata Berbasis Inkuiri Terbimbing di MAN 3 Kediri. Skripsi. Kediri: Universitas Nusantara PGRI Kediri.

[11] Rizqiyana, A.Z. 2014. Pengembangan Lembar Kerja Siswa (LKS) Berbasis Inkuiri Pada Materi Sistem Pernapasan di Kelas Xi SMA Negeri 4 Pekalongan. Skripsi. (Online), tersedia : http://lib.unnes.ac.id Di unduh 30 Desember 2016 : Universitas Negeri Semarang.

[12] Hafshoh, S. (2017). Pengembangan Bahan Ajar Berupa LKS dengan Metode Inkuiri Terbimbing (Guided Inquiry) Pada Pembelajaran IPA Materi Interaksi Makhluk Hidup dan Lingkungannya Kelas VII Semester Genap Di MTS Negeri Kendal. Skripsi. Semarang: Universitas Islam Negeri Walisongo Semarang, 85-93

[13] Lutfiana, Y.F. (2015). Pengembangan Lembar Kerja Siswa (LKS) Berbasis Inkuiri Terbimbing dan Local Material Materi Pokok Sistem Kordinasi Kelas XI IPA 2 MA Negeri Prambon Nganjuk. Skripsi. Kediri: Universitas Nusantara PGRI Kediri.

[14] Rohmah, A.R. 2017. Pengembangan Lembar Kerja Siswa (LKS) Berbasis Inkuiri Terbimbing Materi Gerak Pada Tumbuhan Kelas VIII SMP Negeri 1 Prambon. Skripsi. Kediri: Universitas Nusantara PGRI Kediri.

[15] Lestari, P. 2017. Pengembangan Model Invertebrata Berbasis Inkuiri Terbimbing di MAN 3 Kediri. Skripsi. Kediri: Universitas Nusantara PGRI Kediri. 